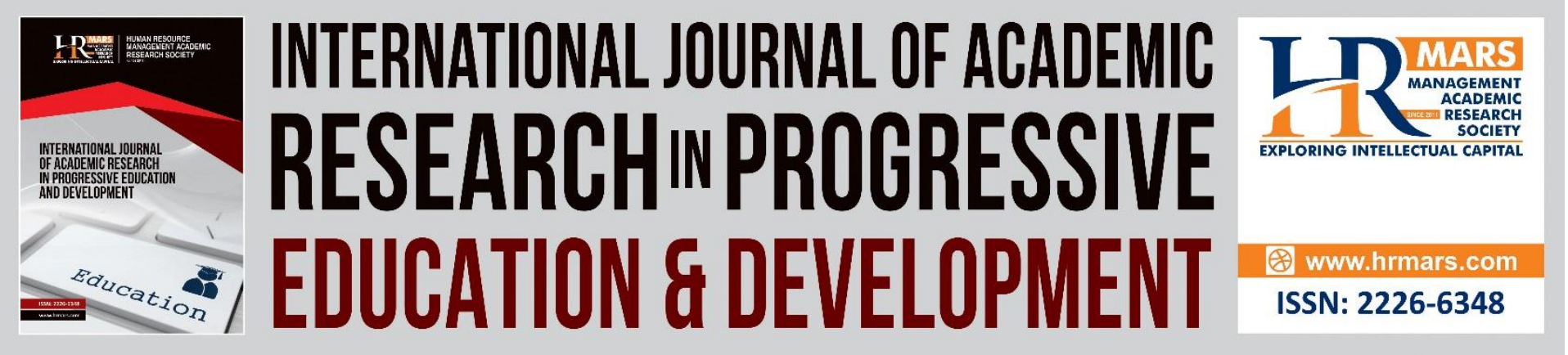

\title{
Role of Principals in Dealing with Challenges Affecting Girl- Child Education in Mixed Day Secondary Schools in Rongo and Ndhiwa Districts, Kenya
}

Odhiambo Rodah Adoyo, Yambo, John M. Onyango

To Link this Article: http://dx.doi.org/10.6007/IJARPED/v1-i4/11997

DOI: $10.6007 /$ IJARPED/v1-i4/11997

Received: 11 September 2012, Revised: 13 October 2012, Accepted: 19 October 2012

Published Online: 21 November 2012

In-Text Citation: (Adoyo \& Yambo, 2012)

To Cite this Article: Adoyo, O. R., \& Yambo, J. M. O. (2012). Role of Principals in Dealing with Challenges Affecting Girl-Child Education in Mixed Day Secondary Schools in Rongo and Ndhiwa Districts, Kenya. International Journal of Academic Research in Progressive Education and Development, 1(4), 84-117.

Copyright: @ 2012 The Author(s)

Published by Human Resource Management Academic Research Society (www.hrmars.com)

This article is published under the Creative Commons Attribution (CC BY 4.0) license. Anyone may reproduce, distribute, translate and create derivative works of this article (for both commercial and non-commercial purposes), subject to full attribution to the original publication and authors. The full terms of this license may be seen at: http://creativecommons.org/licences/by/4.0/legalcode

Vol. 1(4) 2012, Pg. 84 - 117

Full Terms \& Conditions of access and use can be found at http://hrmars.com/index.php/pages/detail/publication-ethics 


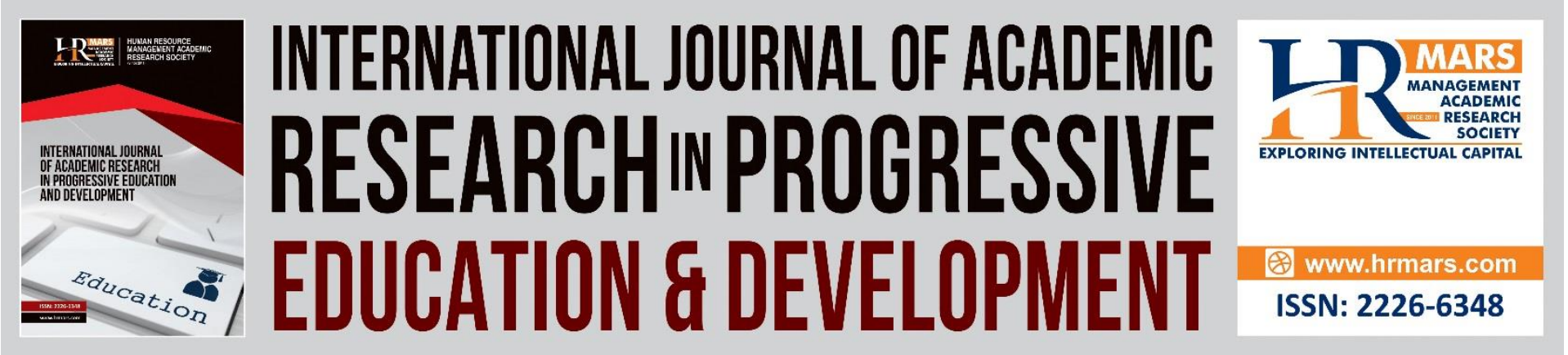

\title{
Role of Principals in Dealing with Challenges Affecting Girl-Child Education in Mixed Day Secondary Schools in Rongo and Ndhiwa Districts, Kenya
}

\author{
Odhiambo Rodah Adoyo \\ Department of Educational Management and Foundations, Maseno University, Maseno, \\ Kenya \\ Email: adoyorodah@yahoo.com
}

Yambo, John M. Onyango

Department of Educational Management, University of Eastern Africa-Baraton (Kamagambo

Adventist College Campus, Kenya)

\begin{abstract}
This study dealt with the Role of Principals in Promotion of Girl-Child Education in Mixed Day Secondary Schools in Rongo and Ndhiwa Districts, Kenya. Objective of the article was to determine strategies principals put in place to deal with challenges that affect girl child participation in education in Rongo and Ndhiwa Districts. The research question was; what strategies do principals use to cope with challenges they face in promoting girl child participation in Education in Rongo and Ndhiwa Districts? The study employed descriptive survey design. The study population was 39 principals, 39 teachers, 2 District Quality Assurance and Standard Officers (DQASO), 39 Board of Governors (BOG) chair persons and 2010 students. Saturated sampling technique was used to select 35 principals 35, teachers and 1 DQASO. Simple random sampling technique was used to sample 325 students. Questionnaires and interview schedule were used for data collection. Three of the schools were used in pilot study to act as pre-test to the instruments of data collection to ensure their reliability. Face validity of the instruments was determined by three experts in the department of Educational Management and Foundation at Maseno University and the impressions on the instruments improved based on the supervisors' advice before using them for data collection. Quantitative data was analyzed by use of descriptive statistics in form of frequency counts, percentages, means and one way ANOVA. Qualitative data obtained from interviews schedule were analyzed in an ongoing process as themes and sub themes emerged from the data. The findings of the study revealed that in order to cope with long distance that girls walked from home to schools, principals created temporary boarding facilities and advised such girls to arrange for means to take them to school so that they don't be late for school. The study will be used to assist the government to come up with better ways of promoting girl child education, identify prospects, challenges and strategies for promoting
\end{abstract}


girls education. This study recommends that parents, teachers, the government and other stake holders should join forces and be responsible for girls' effective participation in education.

Keywords: Kenya, Principals, Promotion, Girl-Child, Participation, Education

\section{Introduction}

Low levels of educational attainment- especially of girl-child represent a very serious constraint on development in most Sub-Saharan African countries. This constraint hampers progress for individuals as well as for nations. At the individual level education is the ultimate liberator, empowering people to make personal and social change. Governments, international organizations, non-governmental organization (NGOs) and researchers have shown a lot of interest in the issues of equality of educational provisions to girls and boys (World Bank, 1988).

There is a wide international recognition that there is no investment more effective for achieving development goals than educating girls. Yet reaching gender equity in school enrolment is still a major challenge in most countries. Nothing illustrates this better than the failure of many countries to attain the only Millennium Development Goal (MDG) fixed for 2015 , which is to eliminate gender disparity in primary and secondary education (World Bank, 2002).

There is a great need for removal of the obstacles hampering girl child enrolment and retention in school; the government has made substantial efforts to achieve wider combination of opportunities coupled with a great concern at primary school level. This is evident in a massive expansion of primary education as tremendous increase in the number of pupils enrolled is being realized, with the government declaration of free primary education (Saitoti, 2003). However, the population of girls decreases as they progress through the grades. As such the impressive enrolment realized nationally has not eliminated gender disparities regionally in the arid and semi arid districts in enrolment rates. As reported girl's completion rate is $35 \%$ against $55 \%$ for boys and this further mark the disparities among the districts (Republic of Kenya, 1997)

Despite the government initiatives in the past decades, the education sector still faces greater challenges and calls for urgent measures of enhancing girl child participation. Each part of the country has its unique characteristics and different intensity of girl-child participation in education (UNESCO, 1997). Transition rate of boys and girls from primary to secondary in the country is thus indicated in Table 1

\begin{tabular}{|c|c|c|c|}
\hline \multicolumn{4}{|c|}{ Table 1 Primary to Secondary Transition Rate } \\
\hline \multirow[t]{2}{*}{ Year in Std 8} & \multirow[t]{2}{*}{ Year in Form 1} & \multicolumn{2}{|c|}{$\%$ of transition to form 1} \\
\hline & & Boys & Girls \\
\hline 2002 & 2003 & 43.60 & 49.8 \\
\hline 2003 & 2004 & 47.20 & 44.30 \\
\hline 2004 & 2005 & 57.70 & 54.20 \\
\hline 2005 & 2006 & 58.30 & 56.20 \\
\hline 2006 & 2007 & 56.50 & 63.20 \\
\hline
\end{tabular}

Source: Statistics and EMS Section, Ministry of education from 2002 to 2006. 
DEVELOPMENT

Vol. 1, No. 4, 2012, E-ISSN: $2226-6348$ (C) 2012 HRMARS

Transition rate from primary to secondary remained below $50 \%$ between years 2002 and 2004 but increased to $56 \%$ in 2005 with boys constituting $57.7 \%$ and girls 54.2\%. The upward trend continued in 2006 and was $59.6 \%$ by2007. This indicator means that as at 2007, 40.4\% of primary school children who sat KCPE exams were not able to progress to the next level.

Table 2 Secondary GER by Gender in Nyanza Province and Nationally, 2002-2009

\begin{tabular}{|c|c|c|c|c|}
\hline \multirow[t]{2}{*}{ YEAR } & \multicolumn{2}{|c|}{ PROVINCE } & \multicolumn{2}{|c|}{ NATIONAL } \\
\hline & Boys & Girls & Boys & Girls \\
\hline 2002 & 34.2 & 25.2 & 29.8 & $26.4^{*}$ \\
\hline 2003 & 32.4 & 28.6 & 29.7 & 27.4 \\
\hline 2004 & 31.9 & 23.1 & 32.1 & 27.6 \\
\hline 2005 & 35.8 & 26.3 & 31.3 & 27.2 \\
\hline 2006 & 37.7 & 28.7 & 34.6 & 29.9 \\
\hline 2007 & 44.4 & 30.6 & 40.4 & 33.3 \\
\hline 2008 & 47.6 & 32.7 & 46.3 & 38.8 \\
\hline 2009 & 50.9 & 34.8 & 49.5 & 41.3 \\
\hline
\end{tabular}

*= Percentage

Source: Statistics and EMIS Section, Ministry of Education (2009).

From Table 2 it was established that Gross Enrolment Rate (GER) increased in the province and in the nation except in the years 2004 and 2005 when the GER for girls dropped at the province. The increase in enrolment may be attributed to the sustained reforms, Free Tuition Secondary Education (FTSE), bursary schemes, the expansion program being undertaken by the government and increased demand of secondary education. In comparison of girls in the province and nationally, it was observed that girls' enrolment was lower at the province and higher at the national level. Over the period under review, boys recorded higher enrolment as compared to girls

Table 3 GER for boys and girls in the nation, Rongo and Ndhiwa Districts from 2002-2011

\begin{tabular}{lccccc} 
YEAR & \multicolumn{2}{c}{ RONGO } & \multicolumn{3}{c}{ NDHIWA } \\
\cline { 2 - 5 } & Boys & Girls & \multicolumn{3}{c}{ Boys Girls } \\
\hline 2002 & 25.8 & 21.3 & 31.1 & $22.6^{*}$ \\
2005 & 29.9 & 16.4 & 32 & 19.5 & \\
2008 & 40.1 & 31.1 & 40.3 & 37.2 & \\
2009 & 37.3 & 26.3 & 38.3 & 34.7 & \\
2010 & 35.3 & 24.4 & 37.4 & 32.8 \\
2011 & 25.6 & 21.3 & 36.6 & 31.4
\end{tabular}

*= Percentage

Source: Statistical return on student enrolment in Rongo District for 2011, D.E.Os office, (2011).

Table 3 indicates the GER for boys and girls in the years that have been shown. It is realized that boys participation in education was more than the girls, in 2002 the difference between boys and girls in terms of GER was 4.5\%, in 2005 the difference was 13.5\%, in 2008 when free secondary education was introduced the GER difference between boys and girls was $9 \%$. However the population of girls decreases as they progress through grades. This is an 
indication that girl child participation in education is still low compared to the boys even if the government has made tremendous effort to provide free secondary education (FTSE) to both boys and girls. There was therefore the need to look at challenges that affect girl-child participation in education.

Table 3 also indicates the enrolment between boys and girls in the years shown. From the table, it is realized that the girls' enrolment is low compared to the boys, for instance the GER difference between boys and girls was $8.5 \%$ in 2002, and in 2005 the GER difference between boys and girls was $12.5 \%$, while in 2008 the GER difference between boys and girls was $3.1 \%$. This is an indication that there are factors that hinder girl child participation in education which this study sought to find out.

Meanwhile in the 2002 KCSE results, $12.7 \%$ of boys qualified for University admission compared to only $5.2 \%$ of girls. In 2003 KCSE results on the percentage pass for girls was only $3 \%$ while that of boys was 97\% in Nyanza province (Aduda, 2004). In Nyanza province 2011 KCSE result analysis, the total number of mean grade A scored were 767 , boys who scored mean grade of A were 709 while girls were 58 . At the same time 2010 KCSE result analysis for Rongo district (Rongo DEOs' Office 2011) indicates that 27 boys got mean grade of A while no girl scored a mean grade of $A$. Ndhiwa district result analysis also indicate that no student managed to get a mean grade of A in Ndhiwa district (Ndhiwa DEOs' Office (2011). Girls therefore need to be helped to better their performance in order to compete favorably with their male counterparts in Nyanza province.

A critical review of literature further revealed that girl child education has been studied from other countries and regions of Kenya. Oloo (2003) has looked at gender disparity in student performance in mixed day secondary schools in Migori district, her study has embarked on the school related and economic factors that contribute to gender disparity in Migori district. Osodo (2008) has looked at the impact of socio-economic factors that hinder promotion of secondary education in Siaya district. Meanwhile Osoro (2008) has also looked at the role of guidance and counseling in mixed day secondary schools in addressing drop out of girls in Siaya district.

\section{Statement of the Problem}

While it is true that girls and boys in the same school, class are often taught by the same kind of teachers, follow the same syllabus and have the same potential as boys, as they move up the academic ladder, the number of girls keep on declining, they tend to lag behind the boys creating a notable disparity with regard to access, retention and completion of secondary education cycle. In Kenya the situation is worrying considering that many girls are enrolled in mixed secondary schools where they are expected to compete daily on a one to one basis in the process of teaching and learning. Studies in Kenya have established that $54 \%$ of girls aged from 12 to 17 are out of school.

It can be observed from Table 1.1 that GER for girls has been low as compared to boys for the period 2002 to 2011 with the GER for girls standing at below 30\% in Rongo District. Despite the governments' effort to introduce FTSE, it is still evidenced that the performance of girls is still low, as in 2005 the GER for boys was $29.9 \%$ while for girls was $16.4 \%$. When FTSE was introduced the GER went up for both sexes as GER for boys was $40.1 \%$ while girls $31.1 \%$. 
However the GER for girls were lower than the boys. In the year 2009 GER for girls went down again from $31.1 \%$ to $23.3 \%$ in 2009 , and at the same time reducing further to $21,3 \%$ in 2011 . The same trend of poor participation in girls is also evidenced in Ndhiwa district as indicated in Table 3, the GER for boys and girls from 2002 to2011. From the table it is realized that girls GER difference between boys and girls was $8.5 \%$ in 2002 and in 2005 the GER difference was $12.5 \%$ while in 2008 when FSE was introduced there was a big difference in term of GER as the boys' was $40 \%$ while the girls $37.2 \%$. From the table it is thus concluded that the girls performance keep declining as the years progress. A critical review of literature further revealed that girl child-education has been studied from other countries and regions of Kenya. However the role of the principals in promoting girl- child participation in education was yet to be explored. The researcher was therefore motivated by this wide gap to carry out the role of the principals in promoting girl-child participation in education in Rongo and Ndhiwa Districts mainly focusing on prospects, challenges and strategies for principals. The principals' central role in school management and administration places them in a position to work with stakeholders in promoting girl child participation in education.

\section{Strategies for Coping with Challenges Principals face as they Promote Girl child Education: Strategies to Cope with Girl-child Pregnancies}

University of Illinois at Urbana campaign (2004) established that teenage mothers need better support including helping them to continue with their education by advising them, proving better child care and increasing the availability of support through housing.

Canadian ministry of education report (1998) also pointed out that appropriate guidance and counseling services have assisted pregnant mothers and teenage mothers as it has helped them to formulate their education plan and assess the various options that are available to help them continue with their schooling. Roye and Balk (1996) also emphasized that adolescents who attended guidance and counseling programs were significantly less likely to drop out of school and had significantly better self esteem.

Studies conducted by Hallam (1994) indicates in his study that FAWE has instituted a number of empowerment programs for girls in collaboration with her national chapters in Ghana, Sierra Leone, Chad, Gambia, Rwanda and Burkina Faso as it invites African women achievers to address the girls on issues of pregnancies and self development.

FAWE (2004) has established that much greater emphasis needs to be placed on effective prevention of both drop out and pregnancies by counseling and extra support for those at risk of dropping out. It established further that as a result of the Mauritius Ministerial Consultation, there are a wide variety of activities in operation in different countries in Africa aimed at reducing pregnancy related school dropout for instance through guidance and counseling services in schools, clubs of various types like Christian union whose role is to instill good morals in young people and teach them about reproductive health and peer education groups which have been very effective in counseling the youth in many countries in Africa

Nyambura, (2000) established further that FAWE in Kenya had emphasized the need for guidance and counseling in schools to curb pregnancy cases. Mlama (2004) established that ministry of education has issued circulars to all PDEs, DEOs and heads of schools and that such re-entry circular formalized re-admission policy and called on the other officers to implement it without delay. Mlama established further that when girls were allowed to resume studies 
after delivery, it would reduce women's illiteracy level; it would empower women to look after their children, would bridge the gender gap in education and would give women a chance to contribute to national development.

Mitchell and Halpern (2003) established that one of the interventions on pregnancies is that girls in schools have formed clubs aimed at using peers or mentors to improve the well being of the girl-child. Such mentors are trained in adolescent reproductive health and counseling, they counsel victims of abuse, and other STI / HIV AIDS and pregnancy related cases.

The current study looked at principals' use of guidance and counseling to cope with girl-child pregnancies in public mixed day secondary schools in Rongo and Ndhiwa Districts.

Bennel, Hyde and Swainson (2002) in their study on the impact of HIV/AIDS epidemic on primary and secondary schooling in Sub Saharan Africa established that school based programs provide the opportunities to start educating children at an early age. They further revealed that there is the use of outside persons to teach HIV/AIDS related issues and at the same time various NGOs do provide HIV/AIDS education and pregnancies services to schools. While Bennel, Hyde and Swainson (2002) have looked at guidance and counseling as becoming strategies to HIV/AIDS, pregnancy related cases in primary and secondary schooling in three countries in Africa, the current study looked at guidance and counseling as a strategy used by principals to cope with pregnancy that is a challenge to girl-child education in public mixed day secondary schools in Rongo and Ndhiwa Districts.

\section{Strategies to Cope with Inability to Pay School Levies}

Ministry of education has identified the country's' education needs as stipulated in the children's Act 2001 and have come up with education policies to promote student education in the country (Dawo 2009). Schools therefore must also identify their unique needs and develop strategies and programs to meet these needs in line with MOE objectives to promote student participation in education.

Babatunde \& Menkiti (2005); Ombuya et al (2012) established that poverty is a major obstacle to participation in education, particularly for girls, when families cannot afford school fees, girls stay at home. They indicated that an important intervention to counter this problem is the provision of bursaries. That this activity as proven to be very effective in expanding girls access and retention in schools. He indicated further that between 1999 and 2000 through funding from UNESCO FAWE Chapters, have benefited from US grants that they have used to promote girl-child education

The school administrators, educators and policy makers are responsible for making the school conducive for learning in terms of motivation, satisfaction and communication to both the teachers and the students. Local NGOs in Mogadishu engage in education of girls and majorly they assist girls who are poor and are not able to pay school fees. They continue and strengthen female promotion programs related to girls' empowerment in education through provision of necessary funding and community awareness programs. They indicated that through such efforts there have been $40 \%$ increase in girls' enrolment at primary and secondary schools engaged in the program (Mogadishu Times, 2010). The current study looked at the strategies principals put in place to cope with girl-child inability to pay school levies in public mixed day secondary schools in Rongo and Ndhiwa Districts. 
DEVELOPMENT

Vol. 1, No. 4, 2012, E-ISSN: 2226-6348 ㄷ 2012 HRMARS

\section{Strategies to Cope with Girl-child Harassment}

World Bank (2004) indicated in its study that increasing girl-child positive attitude towards education is possible by adjusting learning programs to be friendly to the learners by improving the access to and quality of secondary education, teachers being friendly to the girls, providing female teachers as role models, ensuring that teaching content and methods are fair and facilitate the learning of girls, influencing changes in social and cultural practices such as child marriages and also lobbying for legal charges which keep girls in school after pregnancy.

Simatwa (2007) who indicated in his study that to deal with indiscipline among students, teachers were often advised to be committed to creating conducive learning environment, by relating well with the school administration, fellow teachers, students and parents and the community besides showing interest in academic progress, moral growth and the welfare of their students, the students to be given holistic education rather than being pushed to unrealistic levels for dismal performance.

Marube (2007) indicated from his study that school administrators, educators and policy makers were responsible for making the school curriculum and school climate conducive for learning in terms of motivation, satisfaction and communication to both teachers and students. He also indicated that the conducive curriculum and school climate reduced poor participation of the girl-child in learning institutions which is caused by indiscipline, suspension and even expulsion from school. The current study focused on how principals advised teachers and male students to provide conducive environment by not harassing the girl-child to promote their education in public mixed day secondary schools in Rongo and Ndhiwa Districts.

\section{Strategies to Cope with Orphan-hood among Girls}

A study conducted by Bennel, Hyde and Swainson (2002) established that in Malawi there was rapid expansion of NGOs support for orphans since 1990s. That the organizations provide a wide range of services which include residential care, fostering services, advocacy, skill training, guidance and counseling, income generating activities and HIV/AIDS education. They established further that in Uganda there is explicit state provision for orphans with UPE program limited scholarships and provision of bursaries for secondary students. It was further established from their studies that some secondary schools gave fee waivers to orphans who are in financial difficulties or they are allowed to pay their fees in installments, some outstanding orphans have their fees either completely cancelled or paid by the school in exchange for their labor during holidays and weekends.

FAWE (2001) indicated in their study on centers of excellence: case studies from Kenya, Rwanda, Senegal, Tanzania that schools have often become isolated, enclaves having few links with the community and that a majority of the problems faced by girls in schools stem from the home set up and that if strategies for improving girls' education are not anchored in the grassroots, that is in the community that the girl is part of, then these strategies are not likely to yield sustainable result, thus FAWE Centers of excellence decided that to improve quality in schools, communities had to be involved. 
FAWE indicated further that poverty was a major factor hindering the growth of girl-child education and that in such circumstances, a bursary scheme becomes imperative and that in terms of supporting needy girls, the number of bursaries given in the FAWE centers of excellence by both FAWE and the community is big and this means that the community has been fully involved in ensuring girls' access, retention and performance in the centers of excellence. This has been made manifest through involvement in school activities, support for infrastructure and equipment as well as deep sense of ownership for the schools. The study conducted by FAWE established strategies that were used to cope with orphan hood among girls in selected centers of excellence: case studies from Kenya, Rwanda, Senegal, and Tanzania, however, they did not explore how government bursaries were used to cope with orphan-hood as a challenge to girl-child education in mixed day secondary schools in Rongo and Ndhiwa Districts.

Monchari (2012) in his study pointed out that the Ministry of Education science and technology bursary scheme is one of the projects that have been implemented since 1995 to enhance girls' access and participation in Secondary schools education. His study established that Ministry of Education, Science and Technology (MOEST) has done little in addressing gender equality even though some girls have benefited from the MOEST bursary scheme. Kay (2010) in his study pointed out that students have often applied for government bursaries however the trend of allocating bursaries favors boys than girls but in overall, both boys and girls benefited from the bursary scheme.

\section{Principals' Strategies to Cope with Inadequate Physical Facilities}

Kimani, Nekesa \& Ndungu (2009) established that Constituency Development Fund (CDF) is an annual budgetary allocation by the central government to each of the country's parliamentary jurisdiction- the constituencies that seek to bring services and facilities closer to the people so as to reduce poverty. They established that CDF has led to the expansion of education infrastructure through construction of new schools country wide and this improved education to Kenyans especially to boys and girls at the primary and secondary level. Osodo (2008), in his study, observed that the government strived to promote secondary education through the provision of bursaries through CDF. He further established that in Siaya, CDF has mainly been used to construct classrooms, laboratories, and for the provision of other facilities like desks, electrification and sinking boreholes. The bursaries are used to pay school fees for needy students - a practice which is intended to promote secondary school education.

Dawo (2009) in her study established that one of the strategies for the promotion of girl-child education was by the availability of financial resources. The funds were sourced from government grants, free tuition secondary education (FTSE), CDF, School fund-raisings and other well-wishers. She indicated that those funds were used to provide text books, equip laboratories and libraries and to pay bills of water and electricity besides the subordinate staff salaries and to expand and maintain the school. This study focused on the contribution bursaries through CDF, school fundraisings and other well-wishers towards the provision of physical facilities in the school to promote Girl-child education in Rongo and Ndhiwa Districts. 
DEVELOPMENT

Vol. 1, No. 4, 2012, E-ISSN: $2226-6348$ @ 2012 HRMARS

\section{Strategies to Cope with Long Distance to School}

Studies conducted by Dawo (2009) on the girl-child participation in secondary education; opportunities and challenges for mixed day secondary schools in Kisumu municipality proceeded to indicate that to promote girl-child education, more boarding schools were to be established to curb the long distance from home to school, that when more boarding schools were created, it gave girls more time to revise without much interference as it is experienced when they are at home. Neube (2004) in his study established that additional funding had been provided in completion of outstanding infrastructure like laboratories and libraries and in dealing with long distance to school by students, low cost boarding facilities had been introduced in rural day secondary schools.

Action Aid (2004) sums up that to cope with long distance to school from home, girls should be provided with transport and or boarding facilities. That the provision of transport enabled them to reach school early enough and spared them the risk they would undergo if they had to walk the long distance from home o school and also from school to home. The current study sought to establish how principals used temporary boarding facilities to cope with long distance to school that was a challenge to girl-child education.

\section{Methodology}

The study adopted descriptive survey design. Orodho (2003) states that descriptive survey design allows the researcher to gather information summarize it, present and interpret for the purpose of clarification. Borg and Gall (1989) note that descriptive survey research is intended to produce statistical information about the aspects of education that interest policy makers and educators. Fraenkel and Wallen (1993); Yambo et al (2012) define survey as that method that involves asking a large group of people questions about a particular issue. Descriptive survey design was selected for the study because it would establish opinions, attitudes and knowledge about the role of principals in promotion of girl-child education. Any research undertaking involves lots of cost implications hence descriptive survey design was deliberately selected for the study because it allows for quick data collection at a comparatively cheaper cost (Grinnell 1993). The study was conducted in public mixed day secondary schools in the Rongo and Ndhiwa Districts, Nyanza province. Rongo district is one of the districts in Nyanza Province. Saturated sampling technique was used to select 35 public mixed secondary school principals, 35 DOS, 35 BOG chair persons and 1 DQASO as shown in Table 3.0. Simple random sampling technique was used to sample 435 students in Rongo and Ndhiwa districts (33.3\%). According to Bell (1993), a third of the population (33.3\%) was representative enough. Simple random sampling is a procedure that is used to reduce chance variation between a sample and the population it represents (Grinnell, 1996 \& Gall et all, 1996). 
Table 4 Study Population and Sample Size

\begin{tabular}{llll}
\hline Categories of respondents & & & \\
& Sample Size & Population & Percentage \\
\hline Principals & 35 & 39 & 89.7 \\
BOG Chair-persons & 35 & 39 & 89.7 \\
DOS & 35 & 39 & 89.7 \\
Students & 435 & 2010 & 21.6 \\
District QASO & 1 & 2 & 50.0 \\
& & &
\end{tabular}

The research instruments used in the study were questionnaires, and interview schedule. Fraenkel \& Wallen (1993) observe that survey research has four basic way of collecting data namely; administering the instruments "Live" to a group; by mail; by telephone and by face to face interview. Face to face interview was used because it helps enlist cooperation of respondents and to establish rapport with them. Borg \& Gall (1993) observe that questionnaires are often used to collect basic descriptive information from a large sample while interviews are used to follow up questioner responses. The researcher collected data using questionnaires and in depth interview schedules. Questionnaires contained both open ended and closed ended items. Frankel and Wallen (1993) observe that closed ended questions are used in research because they are easy to use, score, and code for analysis while "open ended" questionnaires allowed for individualized response. The study used three types of questionnaires, namely principals Questionnaire (PQ), students' questionnaire (SQ) and teachers' questionnaire (TQ). In-depth interviews were also conducted with BOG chairpersons and DQASO. Descriptive statistics was used for analyzing the resulting data. Gall and Borg, (1996) observe that descriptive statistics are mathematical techniques for organizing and summarizing a set of numerical data. Descriptive statistics was therefore used to analyze information generated from questionnaires and interviews. Quantitative data obtained from closed-ended items in the questionnaires were analyzed using descriptive statistics namely means, frequency counts, percentages and one way ANOVA. One way AVOVA was used to give a clear comparison of the responses on the questions asked by the researcher. Qualitative data obtained from open-ended items from the questionnaires, in-depth interviews were analyzed in an ongoing process as themes and sub themes emerged from the data.

\section{Results and Discussion}

Strategies to Cope with Challenges faced by Principals in Promotion of Girl-child Education To address the challenges faced by principals in promotion of girl-child education, the survey examined strategies that principals used to cope with challenges faced in promotion of girlchild education. The research question responded to was: What Strategies have principals put in place to cope with Challenges they faced in Promotion of Girl-child Education in Rongo and Ndhiwa Districts. In response to this research question the principals, DOS and girls indicated the strategies principals used to cope with challenges faced in the promotion of girl-child education as shown in Table 5 
Table 5 Strategies used by principals to cope with Challenges Faced by Principals in Promotion of Girl-child education as rated by Principals $(n=32)$, DOS $(n=35)$ and Girls $(n=435)$

Strategies Mean Rating

Principals DOS

Girls

(a) Girl-child pregnancies *

Advice to parents

3.59

Guidance and counseling Invitation of guest speakers

(b) Inability to pay school levies*

Application for bursaries

Creation of income

Generating activities

Payment in material

Form

(c) Orphan-hood*

Application for bursaries

Advised to pay school

levies in material form

physical facilities*

Request for CDF

Seek parental assistance

(e) Long distance to school*

Creation of temporary

boarding facilities

4.31

4.13

3.13

4.31

3.13

4.66

3.59

4.34
3.47

3.09

4.19

3.5

4.17

4.57

4.31

4.42

4.24

4.39

3.49

3.19
4.43

4.30

3.44

4.24

3.44 d)Inadequate

Girls arrange for means of transport

(e) Harassment by teachers and male sstudents*

4.63

4.57

Advice to teachers

and male students

4.47

3.57

4.38

Prefects to report cases

of harassment

4.28

4.14

3.74

Teachers encouraged not to push girls too much

3.75

3.63

KEY: $*=$ Challenges

Classification of prospects:

4.1-5.0 Highest prospect

3.1- 4.0 High prospect

3.0 Neutral

2.1- 2.9 Low prospect

1.0-1.9 Least prospect 
The responses in Table 5 indicated that principals had put in place strategies to cope with pregnancy as a challenge to girl-child education. The perception of principals, DOS and girls on strategies to cope with girl-child were made by mean rating.

\section{Strategies to Cope with Girls' Pregnancies}

As shown in Table 5 the study found out that principals had put in place strategies like guidance and counseling of girls, frequent invitation of guest speakers to talk to girls on effects of pregnancies on girls' educational performance and advised parents during parents meetings to counsel their daughters to avoid sexual relations that may lead to pregnancy while still at secondary school going age.

Concerning the use of guidance and counseling to cope with pregnancy cases among the girls was rated 3.47 by principals, 3.49 by DOS and 4.42 by the girls (Table 5). Principals and DOS indicated high scores while girls gave higher scores on the use of guidance and counseling to cope with pregnancy cases in schools. Guidance and counseling has been an effective tool used in schools to cope with indiscipline as it makes one aware of the problem she is in and then opens out one's options on what could be done to correct the problem, it also creates a support system where one can understand the problem and other peoples' behaviors. Girls who had conceived initially were expelled from schools as it was argued that they were a bad example to the other girls who were still in school. However, with the introduction of readmission policy, pregnant girls are allowed to stay in school until when they have delivered.

During such times when they are expectant, guidance and counseling is necessary as it will be an effective way of guiding the girl-child on how to cope at such times. Guidance enables the girls to accept what has happened and therefore change their attitudes and be positive in life when they are expectant and even when they will have delivered. When the expectant girls have changed their attitudes to education, they will then work harder to perform well in class hence promotion of their education.

One BOG chairperson indicated

"During parents meetings, parents were advised to be responsible for their girls and to ensure they advised them accordingly on issues to do with pregnancies and effects of pregnancies in their education".

DQASO was asked during interview on whether principals used guidance and counseling to cope with girl-child pregnancies. DQASO stated

"Guidance and counseling is used by principals in schools to advise girls on various issues like health, pregnancies, career choices and many others. Guidance and counseling are offered by teachers and in some cases principals invited motivation speakers to counsel girls on various issues"

Principals' invitation of quest speakers to school to talk to girls of dangers of getting pregnant was rated 3.47 by principals, 2.86 by DOS and 4.30 by the girls (Table 5 ).

Invitation of guest speakers to guide girls on pregnancy cases is a practice conducted by schools. When the quest speakers are invited, they advise teachers, students, parents and other stakeholders on various issues affecting the school and how to improve the 
performance of the students. After the advice that girls get from the quest speakers, they get encouraged to work harder and with such encouragement, they are likely to improve their performance (Ngaruiya, 2008). From interviews conducted on BOG chair persons, it was revealed that principals invited guest speakers to speak to girls on dangers of pregnancies while in school.

One BOG chairperson stated

"Every year whenever a parents' meeting is held, guest speakers were invited to speak to teachers, students and parents on various academic issues, the core areas discussed were issues that interfered with students' education like absenteeism, lateness in payment of school levies and pregnancies among the girls".

To deal with pregnancy as a challenge, there were various strategies that principals put in place. From the findings of the study, most girls accepted that their principals invited guest speakers to school to talk to girls about various issues. The importance of inviting such guest speakers is that they reminded the girls to keep off factors that may lead to pregnancy and how to behave in case it occurred. BOG chair-persons were also of the afore-mentioned opinion.

BOG chair-persons further indicated that to cope with girl-child pregnancies, those who had conceived and delivered were re-admitted to school. Seventeen percent of BOG chairpersons also showed that one of the strategies that principals should use to cope with girl-child pregnancies was, bringing to book those who impregnated girls. One BOG chairperson noted "Parents, teachers and girls should work together so that they bring to book those men who impregnate the school going girls so that this can act as an example to those who would be planning to have affairs with school girls".

The invitation of guest speakers to facilitate talks on the detriments of pregnancies on academics was another strategy used by the principals to handle pregnancy cases in schools. Girls with mean rate of 4.30 stated that their principals often invited guest speakers to talk to them on the dangers of pregnancy. The current finding concurs with Ngaruiyas' (2008) findings which established that the head-teacher has a role of inviting guest speakers to guide and counsel the girl-child about issues of reproductive health.

The current study agrees with Bennel, Hyde and Swainson (2002) who established from the findings of their study on the impact of HIV/AIDS epidemic on primary and secondary education that school based programs provide the opportunity to start educating children at an early age. They further revealed that there is the use of outside persons to teach HIV/AIDS related issues and at the same time various NGOs do provide HIV/AIDS education and pregnancy services to schools and that schools in Uganda have what are called "senior women and senior men who provide guidance and counseling to both teachers and students on HIV/AIDS and pregnancy related cases. In overall, it was acknowledged by the three respondents that principals promoted girl-child education as they used guidance and counseling, invited guest speakers to advise girls on the effects of pregnancy on their education and advised parents to counsel parents on effects of pregnancies on girl-child education, the strategy used most being advise to parents on the effects of domestic-chores on girl-child education. 
Table 6 ANOVA test on the difference in mean responses by principals, DOS and girls on strategies to cope with pregnancies among girls

The study sought to establish if there was any significant difference in mean responses of principals, DOS and girls on the strategies principals put in place to cope with pregnancies among the girls. To do this ANOVA test was carried out at a P- 0.05 and the results were as in Table 6 below

Table 6 ANOVA test on the Principals Strategies to Cope with Pregnancies among Girls

\begin{tabular}{|c|c|c|c|c|c|}
\hline & $\begin{array}{l}\text { Sum of } \\
\text { Squares }\end{array}$ & Df & Mean Square & $\mathrm{F}$ & Sig. \\
\hline $\begin{array}{l}\text { Between } \\
\text { Groups }\end{array}$ & 29.086 & 2 & 14.543 & 28.127 & .000 \\
\hline Within Groups & 777.116 & 1503 & .517 & & \\
\hline Total & 806.203 & 1505 & & & \\
\hline
\end{tabular}

From Table 6 it was revealed that the P- of .000 was less than the alpha value of 0.05 level of significance. This implied that statistically there was no difference in mean responses of the principals, DOS and girls on strategies to cope with girl-child pregnancies. The girls gave higher responses compared to the principals and DOS may be due to the fact that they were victims of pregnancies and so were aware of what principals did to help them cope with pregnancies. Principals gave high responses and this was considered to be more realistic since they are the ones who experience those challenges and therefore were aware of strategies they had put in place to cope with girl-child pregnancies. DOS' gave high responses may be due to the views that they held on strategies that principals used to cope with girl-child pregnancies.

\section{Principals' Strategies to cope with Girl-child's Inability to Pay School Levies}

Paying school levies in material form as a strategy used by principals to cope with girl-child inability to pay school levies was rated 3.13 by principals, 3.09 by DOS, and 3.44 by the girls.

Girls who are not able to pay school levies are often sent away from school to go and bring school levies. However to due to the realization that poor girls were not able to pay school levies, schools have permitted such girl who could not pay cash to pay school levies in material forms like offering their labor in school after classes, during weekends or during the holidays, supplying the school firewood or wood to be split and use as fire-wood, taking maize or beans to the school or even vegetables. When such materials were accepted by the school, the girl would then stay in school to learn and this would promote their education as they would be present in school without being sent home to go for school levies.

BOG chair-persons were asked to put forth their responses on how principals handled girlchild's inability to pay school levies as a factor affecting girl-child education. Their responses from interviews indicated that principals permitted girls from poor background to pay school levies in material form.

From one of the BOG chair-persons he noted 
"Having realized that some girls came from poor homes and had difficulties in payment of school levies, the principal informed the board members that he had permitted some students to pay school levies in material form, such girls could bring maize, beans fire-wood or even vegetables so that what they took would be converted to school levies"

The perception of the principals, teachers and girls on whether schools had income generating activities by mean rating indicated $4.13,3.20$ and 4.39 respectively (Table 5). Schools have started income generating activities like school vegetable gardens, sugar-cane farms, poultry farms and keeping dairy cattle. Income generating activities are sources of income for the schools and once such sources give adequate income to the school, the principals may decide to allow those who are unable to pay school levies not to pay due to the difficulties that they face. Once such girls are allowed to stay in school, they get the chance to attend classes and get what is taught by the teachers hence promotion of their education.

From interviews conducted with BOG chair-persons it was further confirmed that some schools had income generating activities that helped to cope with girls' inability to pay school levies. One BOG chair-person stated

"The school has a vegetable farm from where vegetables are gotten and cooked for students. The school has kept some dairy cows that also serve as a source of income to the school. Currently the school is planning to start tomato and onion farms so that it gets such commodities from the school directly other than buying them from the market"

DQASO was asked whether principals had started in their schools income generating activities to get more income to promote girl-child education,

DQASO stated

"Principals have often been advised to ensure that if the school has a big piece of land then they use it to start income generating activities to act as other sources of income to the school and I am glad that most of the schools have income generating activities that can subsidize what the girls pay as school levies"

From the findings of the study, it was realized that inability to pay school levies was a factor affecting girl-child education and so principals had to devise ways of dealing with the challenge. It was established from the girls that poor girls were allowed to pay school levies in material form. Nevertheless, some girls disagreed that principals allowed needy girls to pay the levies in material form. DOS (mean rate of 3.09) and principals (mean rate of 3.13) were also of the opinion that needy girls paid school levies in material form.

Advising girls to apply for bursaries to pay school levies was rated 4.31 by principals, 3.20 by teachers and 4.39 by girls. Principals have often encouraged girl-child education by ensuring that girls who are not able to pay school levies pay through application for bursaries. Girls who apply for bursaries are provided with and it is used as school levies and once this is done then girls have an opportunity to be in school and learn without being sent home for school levies, this will therefore promote their education. An interview carried out with BOG chair- 
persons indicated that needy girls were advised to apply for bursaries. One of them emphasized

"Principals advised girls to apply for bursaries, however, despite the advice to apply for bursaries, some girls never did so and thus they often suffered when it came to the payment of school levies"

An interview was conducted with DQASO to establish if principals advised girls to apply for bursaries, DQASO on the other hand stated

"Often bursaries are allocated every year to every district to promote student education. Most students who applied had received except that the number of needy students is high and therefore giving each of then a big figure is rare"

The current study is in agreement with Johnstone, (1986) who established that in the United States bursaries are subsidies awarded to students attending high school and universities on the basis of need as determined by their parents' income and assets. It is given as entitlement without regard to ability, achievement, the particular institution attended or the program of study. He stated further that the actual award depended on the amount appropriated by the congress each year and the number of needs of potential recipients.

In agreement with the current study is Nwagwe, (1992) who conducted a recent study in Nigeria on bursaries and scholarships and revealed that the federal and state governments have given a lot of support to youths in secondary and university education in the form of bursaries and scholarships. His study shows that eighty percent of the bursary and scholarships recipients are found in the rural areas

The current findings agree with Babatunde \& Menkiti (2005) who established that poverty is a major obstacle to participation in education, particularly for girls, when families cannot afford school fees, girls stay at home. They indicated that an important intervention to counter this problem is the provision of bursaries. That this activity has proven to be very effective in expanding girls' access and retention in schools. He indicated further that between 1999 to 2000 through funding from UNESCO FAWE Chapters, have benefited from US grants that they have used to promote girl-child education. The current study is in agreement with the report revealed by Mogadishu Times, (8 Jan 2010) which indicated that local NGOs in Mogadishu engaged in education for girls and majorly they assist girls who are poor and are not able to pay school fees. They continue and strengthen female promotion programs related to girls' empowerment in education through provision of necessary funding and community awareness programs. They indicated that through such efforts there has been a forty percent increase in girls' enrolment at primary and secondary schools.

The current study is in agreement with the study conducted by Bennel, Hyde and Swainson (2002) who in their study of the impact of HIV/AIDS on primary and secondary education in Sub-Saharan Africa established that in Malawi there was rapid expansion of NGOs support for orphans since 1990s. That the organizations provide wide range of services which include residential care, fostering services, advocacy, skill training, guidance and counseling, income generating activities and HIV/AIDS education. They established further that in Uganda there 
is explicit state provision for orphans with UPE program limited scholarships and provision of bursaries for secondary students. It was further established from their studies that some secondary schools give fee waivers to orphans who were in financial difficulties or they are allowed to pay their fees in installments, some outstanding orphans have their fees either paid completely or in exchange for their labor during holidays and weekends and that some secondary schools have come up with income generating activities in Malawi in and out of school even though this is a bit difficult in low income countries, which are unable to resource properly most of such activities.

This view is shared with Dawo (2009) who established that the girl-child in mixed day secondary schools be made to pay affordable school levies for instance they could pay lunch program, school educational tours club activities and infrastructural developments that are reasonable and that others include income generating activities to reduce financial burden on parents, cutting down on luxuries such as expensive meals, and unnecessary tours, informing parents in advance in case of additional school levies and having reliable accounting system that is believable by parents. Ngaruiya (2008) in his study of the role of head teachers in the promotion of girl-child participation in education in Trans Mara District has concurred with the current study as he revealed from his study that principals have a role of raising funds through income generating activities and make deliberate efforts to promote girl-child education. Overally, the three respondents indicated that principals promoted girl-child education by providing strategies to cope with girl-child inability to pay school levies. They acknowledged that principals promoted their education by advising them to apply for bursaries, creation of income generating activities for the school and by allowing such girls to pay school levies in material form.

Table 7 ANOVA test on the difference in mean responses by principals, DOS and girls on strategies to cope with girl-child inability to pay school levies

The study sought to establish if there was any significant difference on mean responses of principals, DOS and girls on the strategies principals put in place to cope with girl-child inability to pay school levies. To do this ANOVA test was carried out at a P- 0.05 and the results were as in Table 7

Table 7 ANOVA test on the Principals Strategies to Cope with girl-child inability to pay school levies

\begin{tabular}{|c|c|c|c|c|c|}
\hline & $\begin{array}{l}\text { Sum of } \\
\text { Squares }\end{array}$ & Df & Mean Square & $\mathrm{F}$ & Sig. \\
\hline Between Groups & 49.377 & 2 & 24.688 & 23.245 & .000 \\
\hline Within Groups & 1063.169 & 1001 & 1.062 & & \\
\hline Total & 1112.546 & 1003 & & & \\
\hline
\end{tabular}

From Table 7 it was revealed that the P- of .000 was less than the alpha value of 0.05 level of significance. This implied that statistically there was no difference in mean responses of the principals, DOS and girls on strategies used by principals to cope with girl-child inability to pay school levies. Both principals and girls gave higher responses to the strategies used to cope with girl-child inability to pay school levies. The response could be due to the fact that once the girls had such a problem, then it was the principals who helped them to cope with such problems. DOS gave their responses may be based on the fact that when it came to matters 
of payment of school levies it was majorly the work of the principals and the accounts clerks, while the DOS dealt with girl-child academic matters.

\section{Strategies to cope with Orphan hood}

Advice to orphans to apply for bursaries was rated 4.31 by principals, 4.57 by DOS and 4.24 by girls. Principals' advice to orphaned girls to pay school levies in material was rated 3.13 by principals, 3.09 by DOS and 3.44 by girls. Principals have often encouraged girl-child education by ensuring that girls who are orphaned apply for bursaries. Girls who apply for bursaries are paid for part of the school levies and once this is done then girls have an opportunity to be in school and learn without being sent home for school levies, this will therefore promote their education. From interviews conducted with BOG chair-persons it was further indicated that principals allowed orphaned girls to pay school levies in material form.

All BOG Chairpersons (one hundred percent) were interviewed on whether Principals advised needy girls to apply for bursaries to pay school levies for promotion of their education. In response to the question more than half of the BOG chairpersons said that needy students were advised to apply for bursaries to pay for school levies so as to promote their participation in education. There was one BOG Chairperson who said

"Principals have advised needy girls to apply for bursaries, the only disappointment is that some girls don't apply, some apply and they don't get the bursary while others apply and they get very little. I have advised parents through chiefs' in "Barazas" to apply for bursaries as it supplements fee payment to needy students".

The other BOG Chairperson stated,

"Principals have often advised needy students to apply for bursaries and those who have applied have always benefited as some of their parents have appreciated the assistance from bursaries in promoting education in the district".

However, a small fraction of BOG Chairpersons who were interviewed said that bursaries did not contribute to girl -child education, one BOG Chairperson had this to say

"School bursaries have not been adequate and regular as sometimes it misses out in many financial years and that the school should take greater responsibility in caring for orphans, because they have the greatest contact with these students and so know them better. Orphans need to be counseled, given love and be helped to build self esteem".

When DQASO was interviewed on whether needy girls applied for bursaries, he said that most needy students who applied were also provided with bursaries even though sometimes others got less than they expected. This finding concurs with Somali media programme (2012) which established that they have provided 168 sponsorships to orphaned and impoverished girls so that they could access quality education. Dawo (2009) proceeded to say that an opportunity for head-teachers in promotion of girl child participation in education was by issuing of bursaries and scholarships to needy girls. 
Monchari (2012) in his study pointed out that the Ministry of Education science and technology bursary scheme is one of the projects that have been implemented since 1995 to enhance girl-child access and participation in Secondary schools education. His study established that Ministry of Education, Science and Technology (MOEST) has done little in addressing gender equality even though some girls have benefited from the MOEST bursary scheme.

Kay (2010) in his study pointed out that students had often applied for government bursaries however the trend of allocating bursaries favors boys than girls but overally, both boys and girls benefited from the bursary scheme. The current study is in agreement with the study conducted by Bennel, Hyde and Swainson (2002) who in their study established that in Malawi there was rapid expansion of NGOs support for orphans since 1990s. That the organizations provide wide range of services which include residential care, fostering services, advocacy, skill training, guidance and counseling, income generating activities and HIV/AIDS education. They established further that in Uganda there is explicit state provision for orphans with UPE program limited scholarships and provision of bursaries for secondary students. It was further established from their studies that some secondary schools give fee waivers to orphans who are in financial difficulties or they are allowed to pay their fees in installments, some outstanding orphans have their fees either completely or in exchange of their labor during holidays and weekends.

The current study is in agreement with FAWE (2001) who established in their study that a majority of the problems faced by girls in schools stem from the home set up and that if strategies for improving girls' education are not anchored in the grassroots, that is in the community that the girl is part of, then these strategies are not likely to yield sustainable results, thus FAWE Centers of excellence decided that to improve quality in schools, communities had to be involved. FAWE indicated further that poverty was a major factor hindering the growth of girl-child education and that in such circumstances, a bursary scheme becomes imperative and that in terms of supporting needy girls, the number of bursaries given in the FAWE centers of excellence by both FAWE and the community is big and this means that the community has been fully involved in ensuring girls' access, retention and performance in the centers of excellence. This has been made manifest through involvement in school activities, support for infrastructure and equipment as well as deep sense of ownership for the schools.

FAWE established further that communities where the centers are located have contributed in terms of resource mobilization. Overally, it was established from the respondents that principals promoted girl-child education as they provided strategies to cope with girl-child harassment. The respondents acknowledged that principals used strategies like advising teachers and male students not to harass girls, advised girls to report to any teacher in case they were harassed by teachers and male students, prefects to report any cases of girl-child harassment to the teachers and encouraged teachers not to push the girls too much beyond their capabilities. 
Table 8 ANOVA test on the difference in mean responses by principals, DOS and girls on strategies to cope with orphan hood.

The study sought to establish if there was any significant difference on mean responses of principals, DOS and girls on the strategies principals put in place to cope with girl-child orphan-hood. To do this ANOVA test was carried out at a P- 0.05 and the results were as in Table 8

Table 8 ANOVA test on the Principals Strategies to Cope with Orphan hood among Girls

\begin{tabular}{llllll}
\hline & $\begin{array}{l}\text { Sum } \\
\text { Squares }\end{array}$ & of & & & \\
Between & 49.377 & 2 & 24.688 & 23.245 & .000 \\
$\begin{array}{l}\text { Groups } \\
\text { Within }\end{array}$ & 1063.169 & 1001 & 1.062 & & \\
$\begin{array}{l}\text { Groups } \\
\text { Total }\end{array}$ & $\mathbf{1 1 1 2 . 5 4 6}$ & $\mathbf{1 0 0 3}$ & & & \\
\hline
\end{tabular}

From Table 8 it was revealed that the P- of .000 was less than the alpha value of 0.05 level of significance. This implied that statistically there was no difference in mean responses of the principals, DOS and girls on strategies used to cope with orphan hood. These differences may be attributed to the fact that girls did not have all information matters to do with school administration especially on how principals coped with girls from poor families. DOS were also aware on whether schools had income generating activities or not and so they gave their responses based on what was on the ground. Principals gave their responses based on the fact that they were aware of how they advised girls from poor background to apply for bursaries and how income gotten from income generating activities helped to cope with the challenge of girl-child orphan hood.

\section{Strategies to cope with Inadequate Physical Facilities in School}

Principals' use of CDF to cope with inadequate physical facilities was rated 4.66 by principals and 4.17 by DOS. Provision of CDF encouraged girl-child education as money gotten from CDF may be used to establish physical facilities or to improve the existing facilities. Money from CDF has also been used in schools to provide water, electricity and even construction of school buildings. When such facilities are provided in the schools, girl-child education may be promoted as they stand chances of getting adequate facilities that was not adequate previously. Schools that lacked electricity may be provided with the facility hence promoting their education, schools that lacked facility like staff-room will construct such as they will have received the fund that can be used for such hence promotion of girl-child education when such facilities are provided through CDF.

Principals' use of funds-drive to cope with inadequate physical facilities was rated 3.59 by principals, 4.57 by DOS and 4.31 by girls. From the interview conducted with BOG chairpersons and DQASO it was established that CDF had contributed to the establishment of most of the school facilities as most of the schools had been provided with CDF.

From interviews conducted with BOG chairpersons it was realized further that principals often invited parents to school to contribute to the establishment of more educational facilities to 
promote girl-child education. It was further confirmed from DQASO that principals invited parents for funds drive to help in the establishment of more educational facilities to promote girl-child education.

From the findings of the study, it was established that Principals had put in place various strategies to cope with inadequate facilities in the school. Principals (mean rate of 4.66) and DOS (mean rate of 4.17) established that principals used CDF to construct or renovate school facilities to improve girl child education. The higher score indicated by the principals was proof that they sought for assistance from CDF to cope with inadequate facilities in schools.

BOG Chairpersons were asked if their schools requested for CDF and what they used it for, most of them indicated that they requested for and when they were given they used it for various purposes. One BOG Chairperson established,

"CDF has promoted building of physical facilities like classrooms, latrines; dig a borehole in the school while government bursaries supplemented fee payment for needy students".

Another BOG Chairperson stated,

"CDF has facilitated the construction of adequate classrooms, temporary dormitories, library and a laboratory for the school".

DQASO was asked if schools had received CDF for improvement of school physical facilities. He said that most of the schools were provided with CDF that were used for various purposes in the schools. In agreement with the contribution of CDF in providing more physical facilities in schools are Kemani, Nekesa and Ndugu, (2009) in their study indicated that CDF is an annual program that was established by CDF Act of 2003, it was one of the indigenous innovations of the National Rainbow Coalition (NARC) government of Kenya. They established from their study that CDF had led to the expansion of education infrastructure, through the construction of new schools countrywide, it has improved accessibility of education to Kenyans especially boys and girls. Ngaruiya (2008) in his study posited that CDF has relieved parents from the burden of constantly repairing mud walled classrooms as children now learnt from favorable conditions and that the increase of the number of schools and classrooms reduced crowding in schools. He proceeds to indicate that the schools have been equipped with books, desks, chairs, laboratory equipment and that this coupled with FPE and FTSE has increased both primary and secondary school enrolment. In agreement with the current study are Kakonge, Kirea, Gitabu and Nyamu (2001) who on their report indicated that among the most important interventions by governments are grants in aid to secondary schools in ASAL. Others include girl-child projects, boarding and mobile schools for nomadic girls. That intervention by NGOs include material support for construction of classrooms, bursaries, food, clothing, health care for the very poor, provision of learning resources and human resource development through training seminars and workshops. Respondents also cited the other strategy to cope with inadequate facilities in the schools; Principals, DOS and girls with mean rates of 3.59, 4.57 and 4.31 respectively (Table 4.10) indicated that parents contributions were also sought through funds drive to cope with inadequate facilities. The respondents mean rate were higher indicating that Principals called for funds drive and invited parents to attend school functions and contribute towards improvement of school physical facilities. BOG Chairpersons were asked if parents were asked to contribute towards the provision or improvement of school 
physical facilities. All BOG Chairpersons (100\%) said that they had sought parents' assistance and through that they had done a lot in the schools. One BOG chairperson stated,

"For us to construct class rooms or toilets, staffrooms, we organize for Harambee where we invite parents, friends and well wishers contributions. Their responses have been good and has enabled us come up with some physical facilities in the school."

Another BOG chairperson noted,

"The laboratory structure was built through funds drive where parents, friends and well wishers contributed. Nevertheless, it was made operational by CDF fund. Students from my school are the direct beneficiaries because it is currently in use while the community around the school are indirect beneficiaries since they can take their children in a near by school that has school facilities".

DQASO was also asked through an interview if parents were asked for donations to cope with the challenge of inadequate facilities that affected girl child education.

He noted

"Schools in the district have had at one time or another organized for Harambee and in such Harambee, parents had often paid a specific amount towards the project and they are also required to contribute during the actual Harambee when other friends and well wishers came to give their contribution".

This finding concurs with Nyaruiya (2008) who also pointed out that principals have to put physical facilities in the school through their board of governors and also ensure the school is well fenced to keep out intruders and for the safety of school facilities.

The finding of the current study is in line with Majiwa (2005) who pointed out in his study of factors that affect participation of girls in secondary education in Turkana District that CDF has enhanced girl-child participation in education with a number of girls accessing school due to the fund. Ncube (2004) also alludes from the findings of his study on managing the quality of education in Zimbabwe: the internal efficiency of rural day secondary schools that principals have to look for various sources of income to cope with inadequate facilities in schools. He established in his study of managing the quality of education in Zimbabwe: the internal efficiency of rural day secondary schools that more funding is already allocated to rural day secondary schools to boost resources and curtail drop outs, he established further that more funding has assisted in the completion of outstanding infrastrure like libraries and laboratories.

This view is shared by Gatawa (1998) who observed that the rural poor in Zimbabwe could not send their children to school, hence the government embarked on an ambitious program to set up rural schools where parents provide labor and building materials. Therefore according to Gatawa (1998) he established from the findings of his study on quality-quantity dilemma in education: the Zimbabwean experience that 1980 to 1989 saw the construction of schools in rural areas where no secondary schools existed before to the social demand. Zvogbu (1986) further underscores the thrust to develop day secondary schools when he observes from the findings of his study on that considerable resources were being made 
available to all interested authorities to enable them to provide facilities for secondary education in rural areas. Overally, the three respondents indicated that principals promoted girl-child education as they provided strategies to cope with inadequate physical facilities in schools. Such strategies were seeking parental assistance through funds drive and requesting for bursaries.

Table 9 ANOVA test on the difference in mean responses by principals, DOS and girls on strategies to cope with inadequate facilities in school

The study sought to establish if there was any significant difference on mean responses of principals, DOS and girls on the strategies principals put in place to cope with inadequate facilities in schools. To do this ANOVA test was carried out at a P- 0.05 and the results were as in Table 9 below

Table 9 ANOVA test on the Principals Strategies to Cope with inadequate Facilities

\begin{tabular}{|c|c|c|c|c|c|}
\hline & $\begin{array}{l}\text { Sum } \\
\text { Squares }\end{array}$ & Df & Mean Square & $\mathrm{F}$ & Sig \\
\hline Between Groups & 14.513 & 2 & 7.257 & 22.347 & .000 \\
\hline Within Groups & 325.049 & 1001 & .325 & & \\
\hline Total & 339.562 & 1003 & & & \\
\hline
\end{tabular}

From Table 9, it was revealed that the P- of .000 was less than the alpha value of 0.05 level of significance. This implied that statistically there was no difference in mean responses of the principals, DOS and girls on strategies that principals used to cope with the challenge of inadequate physical facilities. When the responses of the principals and DOS were compared, it was realized that there was no significant difference between them and this may be due to the fact that principals, DOS and girls knew on what was done to cope with inadequate facilities. However whenever parents were called upon to come for funds' drive for the schools, both DOS and the girls would get to know and so they gave informed views based on what they saw when parents were invited to school for funds' drive.

\section{Strategies to cope with Girls' Long Distance from School}

Principals' creation of temporary boarding facilities to cope with long distance to school was rated 4.34 by principals. DOS rated 3.49 and the girls rated 3.19 .

Creation of temporary facilities may provide girls who come from a long distance from school to stay in school. Living in school by girls saves them from the challenges they face as they went to school. This gives them time after classes to conduct private studies or do home-work that is assigned to them by the teachers. When the girls get time to carry out such academic duties, they get to understand various academic concepts and hence promotion of their education.

Principals also advised girls who came from far away from school to arrange for better means to school and this was rated 4.19 by principals, 3.54 by DOS and 3.68 by girls.

Interviews conducted with BOG chair-persons and DQASO also confirmed that in some schools principals provided temporary boarding facilities to girls whose homes were far from 
home so that they could find it easier to settle in school without walking back to home after classes.

BOG Chair-persons also acknowledged through interviews conducted with them that some schools had put in place temporary boarding facilities that assisted those girls who came from long distances to school. One BOG Chair-person established noted

"Because some students come from as far as more than $3 \mathrm{kms}$ from home to school, some classrooms have been turned into dormitories to accommodate such students, some teachers and watchmen ensured the safety of such students who were accommodated in schools".

\section{Another BOG Chairperson had this to say}

"In order to get sufficient time to revise all the students who came far from school put up in the school and teachers normally taught them some times in the night or at dawn".

When DQASO was asked if he was aware that some schools provided temporary boarding facilities to students who travelled long distance from home to school he said that he was aware that some schools provided temporary boarding facilities especially to students whose homes were far from school and it also saved time for students who would have otherwise have wanted to go back home for lunch then come back to school.

This finding is in line with the view held by Neube (2004) who established that additional funding had been provided in completion of outstanding infrastructure like laboratories and libraries and that in dealing with long distance to school by students, some low cost boarding facilities had been introduced in rural day secondary schools. Dawo (2009) proceeds to indicate in her study that to promote girl-child education, more boarding schools were to be established to curb the long distance from home to school that girls experience and to give them more time for revision. Action Aid (2004) sums up that to cope with long distance to school from home, girls should be provided with transport and or boarding facilities and the study conducted by Action Aid is in agreement with the current study which established that temporary boarding facilities would help cope with long distance to school that was a challenge to girl-child education. Overally, the three respondents indicated that principals promoted girl-child education by providing strategies to cope with long distance to school that was a challenge to girl-child education. Strategies that principals put in place to cope with long distance to school were advising girls to arrange for better means of transport to take them to school early and creation of temporary boarding facilities in schools to help such girls.

Table 10 ANOVA test on the difference in mean responses by principals, DOS and girls on strategies to cope with girl-child long distance to school

The study sought to establish if there was any significant difference on mean responses of principals, DOS and girls on the strategies principals put in place to cope with girl-child long distance to school. To do this ANOVA test was carried out at a P- 0.05 and the results were as in Table 10 
Table 10 ANOVA test on the Principals Strategies to Cope with girl-child long distance to school

\begin{tabular}{|c|c|c|c|c|c|}
\hline & $\begin{array}{l}\text { Sum } \\
\text { Squares }\end{array}$ & Df & Mean Square & $\mathrm{F}$ & Sig. \\
\hline Between Groups & 41.099 & 2 & 20.549 & 11.946 & .000 \\
\hline Within Groups & 1721.865 & 1001 & 1.720 & & \\
\hline Total & 1762.964 & 1003 & & & \\
\hline
\end{tabular}

From Table 10, it was revealed that the P- of .000 was less than the alpha value of 0.05 level of significance. This implied that statistically there was no difference in mean responses of the principals, DOS and girls on principals' strategies to cope with the challenges of long distance to school. The insignificant differences may be due to the difference in opinion of the respondents on the strategies that principals used to cope with long distance that interfered with girl-child education. Girls also gave higher responses since they knew how often principals had helped them to cope with this challenge. In schools DOS' knew the effect of girl-child long distance from home to school on their academic performance. From the study it was therefore concluded that DOS were aware of whatever strategies that principals used to cope with this challenge even though principals' responses were considered to be more realistic since they were the ones who experience those challenges and therefore were aware of the strategies they had put in place to cope with the challenge of long distance to school.

\section{Strategies to cope with Harassment of Girls by Teachers and Male Students}

It was established that principals with mean rate of 4.63 indicated that teachers and male students were advised to create conducive learning environment for the girls by relating well with them. DOS indicated their perception by mean rate of 4.57 that they were advised to create conducive learning environment by ensuring they related well with the girls.

To cope with harassment of girls by teachers and male students it was further established that principals encouraged teachers to avoid thoughtlessly pushing girls too far in academic pursuit. The principals and DOS gave their perception by mean rate of 3.75 and 3.63 respectively.

From interviews conducted with BOG chairpersons, one of the BOG chair-persons noted "Some girls were slow learners who would only make little progress and as such it was not necessary to thoughtlessly push them too far in academic pursuit because pushing them too far discouraged them and made them look at education negatively".

The perception of principals on encouragement of prefects to inform teachers of male students who harassed girls was rated 4.28. The perception of teachers on prefects informing teachers about male students harassing girls was rated 4.14 while the perception of girls on whether prefects were encouraged to inform teachers about male students who harassed girls was rated 3.74. Prefects have a duty to ensure that both boys and girls learn comfortably without a student interfering with the other students. It is also upon every student to report any case of harassment to the prefects or the teachers so that action can be taken against such boys who harassed girls. When male students realized that prefects report them when 
they harass girls, they refrained from such acts. When they refrain, girls will not be harassed hence they learn freely without fear of being harassed by male students hence promotion of girl-child education.

Principals informing girls to report cases of harassment to teachers was rated $4.47,3.57$ by DOS and 4.38 by girls. Advice to teachers and male students to create a conducive learning environment by relating well to the girls was rated 4.63 by principals and 4.57 by DOS. Learning takes place in a conducive environment, where teachers and girls learn freely, interact freely and can share ideas without any form of fear, when the teachers provide such conducive atmosphere then the girls also get encouraged to learn and ask questions during lessons as they are assured of no harassment during teaching and learning sessions.

Encouragement of teachers not to push girls too much to cope with girl -child harassment rated 3.75 by principals and 3.63 by DOS. Interviews conducted with BOG Chair-persons indicated that teachers were reminded not to push girls too far as slow learners would find it hard to stay in such difficult situations. One BOG chairperson noted:

"Some girls are very shy and naïve if they are pushed too far, they may fear the teacher and may be absent to avoid that lesson taught by the teacher who pushes them too far, some may resort to transfer to other schools if the learning environment is not conducive".

For effective participation of girl-child in education, principals and teachers have to provide conducive environment for learning.

This finding concurs with Simatwa, (2007) who indicated that to deal with indiscipline among students, teachers were often advised to be committed to creating conducive learning environment, by relating well with the school administration, fellow teachers, students and parents and the community besides showing interest in academic progress, moral growth and the welfare of their students, the students had to be given holistic education rather than being pushed to unrealistic levels for dismal performance. To cope with harassment of girls by teachers and male students respondents indicated that principals informed the school prefects to report to any teacher around any male student who harassed them. When fellow students realized that prefects would report them in case they harassed girls, they stopped such habits knowing if they did such then teachers would punish them. Shunning such practices among male students was to the advantage of the girls as it gave them a chance to study without much interference.

Table 11 ANOVA test on the difference in mean responses by principals, DOS and girls on strategies to cope with girl-child harassment

The study sought to establish if there was any significant difference on mean responses of principals, DOS and girls about the strategies principals put in place to cope with girl-child harassment. To do this ANOVA test was carried out at a P- 0.05 and the results were as in Table 11. 
INTERNATIONAL JOURNAL OF ACADEMIC RESEARCH IN PROGRESSIVE EDUCATION AND

DEVELOPMENT

Vol. 1, No. 4, 2012, E-ISSN: 2226-6348 @ 2012 HRMARS

Table 11 ANOVA test on the Principals Strategies to Cope with Girl-child harassment

\begin{tabular}{|c|c|c|c|c|c|}
\hline & $\begin{array}{l}\text { Sum } \\
\text { Squares }\end{array}$ & Df & Mean Square & $F$ & Sig. \\
\hline Between Groups & 4.315 & 2 & 2.158 & 3.914 & .020 \\
\hline Within Groups & 625.724 & 1135 & .551 & & \\
\hline Total & 630.040 & 1137 & & & \\
\hline
\end{tabular}

From Table 11 it was revealed that the P- of .020 was less than the alpha value of 0.05 level of significance. This implied that statistically there was no difference in mean responses of the principals, DOS and girls on the challenges faced by principals to cope with girl-child harassment by teachers and male students. The insignificant difference may be due to the actual occurrences in the schools on the girls and strategies principals put in place to cope with the challenges. The insignificant difference was may be due to the fact that principals and DOS were the ones who experienced this challenge most and were aware of the strategies that had been put in place to cope with girl-child harassment. Girls also gave low responses compared to the principals as may be they might not have known all the strategies that were used by principals to cope with girl-child inability to pay school levies.

\section{Conclusion}

This study made the following conclusion based on the findings:

Principals used various strategies to cope with challenges they faced as they promoted girlchild education. For instance, to deal with pregnancies, the principals employed the strategy of guidance and counseling of girls, invitation of guest speakers to advice girls and advice to parents to guide their girls and to know how to cope with pregnancy cases among the school going girls. To cope with girl-child inability to pay school levies, principals employed strategies like permitting such parents to pay school levies in material form, advised such girls to apply for bursaries and created income generating activities to be other sources of income for the school to promote girl-child education. In dealing with girl-child harassment by teachers and male students, principals employed strategies like advising teachers and male students to create a friendly environment for girls by not harassing them, teachers were encouraged not to push girls too much beyond their intellectual ability, prefects to report those boys who harassed girls and that girls too to report cases of harassment to the teachers. To cope with orphan-hood as a challenge to girl-child education principals employed strategies like advising girls to apply for bursaries and being permitted to pay school levies in material form. Strategies that principals used to cope with inadequate facilities in school were requesting for CDF and seeking financial assistance from parents and well wishers. To cope with long distance that girls walked from home to schools, principals created temporary boarding facilities and advised such girls to arrange for means to take them to school so that they don't be late for school.

\section{Recommendation}

With regard to strategies to cope with challenges faced by principals as they promoted girlchild education, it is recommended through this study that parent, teachers and girls, the government and other stake holders to join forces and be responsible for girls' effective participation in education. 


\section{References}

Abagi, O., Wamahiu, S., \& Owino, W. (1997). Household based Factors as Determinants of School Participation of Girls in Kenya: The Case of Nairobi and Siaya Districts. Abridge Research Report Nairobi: Academy Science Publishers.

Abagi, O. (1992). Addressing the gender gap in education in an emerging demographic Action Aid. (2004). Stop Violence Against Girls: Nairobi: Action Aid Kenya.

Aduda, D. (2004). Precious Blood tops again. Daily Nation. P 4-5. Kenya society. Workshop on education and democratization, May 1992.

AWE. (2006). Brave little bear: Teenage pregnancy and education. AWE. Australia. www.bravelittlebear.com.au/resources. Retrieved on 29/4/2012) Nation Media Group. P6.

Ballara, M. (1992). Women and Literacy; Women and Development Series. London: Zed Books LTD.

Bendera, S. J., \& Mboya, M. W. (1996). Gender and Education in Tanzanian Schools. Dar es Salaam University Press.

Bennell, P. S., Hyde, K., \& Swainson, K. (2002), The Impact of HIV/HIDS on Education sector in Sub-Saharan Africa. The main findings and Recommendations of three country study. Centre for International Education. Sussex University, Brighton.

Bhindhe, A. A. (1994). A study of the sexuality of Adolescent Girls and Boys in Underprivileged Groups in Bombay. Indian Journal of Social WorkVol,2 P 8

Bohitile, C. (2000 November 18). How harassment of girls in schools lead to dropout. East African Standard P.17.

Borg, R. W., \& Gall, M. D. (1989). Educational Research; An Introduction. (6 ${ }^{\text {th }}$ Ed.). Columbus, $\mathrm{OH}$ : Merill Publishing Company.

Bishop, J. J. (1982). "The Effect of Selected Variables on School Attendance assessed by Good, Average, and Poor School Attenders". Dissertation Abstract International :Vol 43 pp 2169.

Candiru, E. (1991). Teenage Sexuality and Childbearing: its Impacts on Girls Education in Uganda. Seminar report.

Chege, A. (1993). Research Priorities in areas of School Facilities: Presented at the Education Research Priority Seminar at Mombasa on $12^{\text {th }}-14^{\text {th }}$ November.

Chege, F., \& Sifuna, D. (2006). Girls and Women's Education in Kenya. Gender perspective and trends. Nairobi: UNESCO.

Daily Nation. (1994). Enrolment Decline in Schools, Nairobi, Kenya: Nation Newspaper Limited (P8).

Dawo, J. I. A. (2008). Girl Child Participation in Secondary Education; Opportunities and Challenges for Mixed Day Secondary School head teachers in Kisumu Municipality. Unpublished Masters Thesis, Maseno University.

D.E.O. (2011) Statistical Return on Student Enrolments. Dhiwa: D.E.O

D.E.O. (2010). Statistical Return on Student Enrolments. Dhiwa: D.E.O

D.E.O. (2010). Statistical Return on Student Enrolments. Rongo: D.E.O

D.E.O. (2009). Statistical Return on Student Enrolments. Rongo: D.E.O

Dfes. (2004). National standards for Head teachers, Guidance Organization \& Management. Nottingham, England: Department of education and skills.

Dolyphyne, F. A. (1991). The emancipation of women: Creating an enabling environment for girls in schools. An African perspective. 
Dorsey, B. J. (1996). Socialization, Gender, Academic Achievement and Aspirations of Secondary School Students in Zimbabwe. Harare HRRC.3.

Duncan, W. (1998). School Dropout in Botswana: Gender Difference at Secondary Level. Stockholm. University of Stockholm (IIEMP).

EMACK. (2012). Empowering the Girl-child: School Based Forums. USAID Kenya.

Eshiwani, G. S. (1985). Women's access to higher education in Kenya: Opportunities and entertainment in science and mathematics education. Journal of East Africa research and development vol. 15. P20

Eshiwani, G. S. (1993). Factors Influencing Performance among Primary and Secondary Pupils in Western Kenya: A Policy Study. Nairobi: Bureau of Educational Research, Kenyatta University.

Ezewu. (1983). Sociology of education. London: Longman.

FAWE. (1994). FAWE News Vol 5 No.1. Nairobi: FAWE.

FAWE. (1997). Building effective partnerships for girls' education in Africa. A report of the second ministerial consultation $13^{\text {th }}-14^{\text {th }}$ October, Dakar.

FAWE. (2000). Closing the gender gap in education: curbing dropout, vol.8 No.3 July - September. P11.

FAWE. (2001). Vol. 9 No. 1 Jan - March. P21.

FAWE. (2004). Keeping Girls in School: FAWE Zambia's Campaign for an Enabling Re-admission Policy for Adolescent Girls. FAWE

FAWE. (2007). Girls Academic Achievements' Realizing the Full Potential. Nairobi: FAWE. P15. Gall, M., Borg, W., \& Gall, W. J. (1996). Educational research. An introduction (6 $6^{\text {th }}$ (edition). New York: Longman.

Gatawa, B. S. M. (1998). Quality-Quality Dilemma in Education: The Zimbabwe Experience. Harare: Zimbabwe Government.

Gender Report. (2004). The Status of Gender Equity and Equality in Primary Education in Kenya. Girl-child Network. Nairobi: Kenya.

Gogo, J. O. (2002). Effects of Cost Sharing Strategy on Access and Quality of Secondary Schools in Rachuonyo Disrict. Unpublished Masters Thesis Maseno Uni .

Hallam, S. (1994). Crimes without Punishment: Sexual Harassment and Violence against Female Students in Schools and Universities in Africa. Discussion Paper No.4. London: African Rights.

Hyde, K. (1995). Priority research: Themes on female education in Africa. Nairobi: Academic science press.

Jagero, N. O. (2010). Cost Effectiveness Analysis between Day and Boarding Secondary Students in Kisumu District. Unpublished PHD thesis Maseno Uni.

Johnstone, P. B. (1986). Sharing the cost of Higher Education. NY, New York College Entrance Examination Board.

Juma, M. N. (1994). Determination of Female Participation in Primary Education: A Study of Kwale and Taita Taveta Districts. Unpublished PhD thesis. Kenyatta University.

Juma, G. (2003). The Nature trend and factors causing wastage in secondary schools in Vihiga District. Unpublished Masters Thesis. Maseno University.

Kadzamira, E., Swan, N., Banda, D. M., \& Kamlongera, A. (2001). The impact of HIV/AIDS on formal school in Malawi. Brighton: Center for International Education, University of Sussex Institute of Education.

Kasante, D. H. (1998) Processes Influencing Gender Differences in Achievement in Primary and Sec. Education. Research Framework No.2:Nairobi Academy Science Publishers. 
Kasante, D. H. (1995). Processes Influencing Gender Differences in Achievement in Post Secondary Institutions in Uganda. Abridged Research Report. Nairobi: Academy Science Publishers.

Kiilu, N. P. (1990). Factors that Affect Performance in Urban Day Schools in Migori District. Unpublished Masters Thesis. Maseno University.

Kissman, K. (1998). High Risk Behavior among Adolescent Mothers. International journal of adolescence and youth Vol. 2, No 4, P7.

Klasen, S. (2002). Does Gender Inequality Reduce Growth and Development? Evidence from Cross Country Regressions. World Bank Policy Rerearch working paper No.7. Washing ton D.C: World Bank.

Koje, C. (1996). Gender Gap in Access to Education in Nigeria Focus Group Discussion with Adult Men and Women in Haogboli, Ondo State. A Bridged Research Report NO, 14. Nairobi: Academy Science Publishers.

Ncube, N. J. (2004). Managing the Quality of Education in Zimbabwe: The Internal Efficiency of Rural Day Secondary schools. Unpublished PhD Thesis. University of South Africa

Nyangesa, A. M. (2008). Pupil Wastage in Public Primary Schools in Nandi District Unpublished Masters Thesis. Maseno University.

Nyatoke, F. (2007). Effects of Socialization with Regard to Gender roles in Students' Academic Achievements in Secondary Schools in Kisii Central District. Unpublished Masters Thesis. Kenyatta University.

Ngaruiya, T. K. (2008). The role of Principals in the promotion of Girl-child Participation in Education in Trans-Mara District. Unpublished

Masters Thesis. Maseno University.

Ng'weno, H. B. (1994). The Cost of Wastage in African Education Systems: Keynote Address". Report on Ministerial Consultation September 15 - 18, Mauritius. Forum For African Women Educationists.

Nkinyangi, S. (2005). Education for All. English 2005.

Htt.//www.education.nairobi.unesco org./ PDI Retrieved on 29/4/2010

Khayesi, M., Mackenzi, M., \& Sambili, H. (1997). Kenya Women Education and Status in the Nyayo Era, with a bibliographic reference of role models. Nairobi. Instaprint

Kirui, P. K. (1982). A Study of Factors that Influence the increasing Repetition Rates in Primary Schools in Nandi District. Unpublished Masters Thesis. University of Nairobi.

Kwamboka, O. (2008). Teenage mums denied education. http://:pnews.net/africa.nota/esp?idnews=4287. Retrieved on 10/12/11

Lloyd, C. B. (2006). Girls in developed countries. Highlights from population council research. http://:www.pop.council.org/pdfs/TABriefsPGy. Brief-24 educ. Pdf. Retrieved $15 / 8 / 2011$.

Majiwa, O. P. (2005). Factors that Affect the Participation of Girls in Secondary Education in Turkana District. Unpublished Masters thesis. Kenyatta University

Maleche, A. J. (1972). A new Status for Women in Kenya. East African Journal, Ministry OF Education (1998): East African Standard. August 1st 1998 Nairobi, Standard Newspaper

Marube, R. (2007). The Role of Guidance and Counseling in Mixed Day Secondary Schools in Addressing Drop out of Girls in Siaya District. Unpublished Masters Thesis. Maseno University.

Michieka, E. N. (1983). An Investigation of causes of Pupil Dropout in Primary schools in Kisii District of Kenya. Unpublished Project report, University of Nairobi.

Mulwa, N. C. (1998). Pupils, Teachers, Parents Perception of Causes of Absenteeism 
and Dropping out in Primary Schools in Arid and Semi Arid Areas. A case study of Keiyo District. Moi University: Unpublished MPhil Thesis.

$\mathrm{MOH}$. (1998). Schoolgirls pregnancy in Kenya. Report of a study of discontinuation rates and associated factors, March.

Mwamwenda \& Mwamwnda. (1987). School Facilities and Student Performance in Schools.

Mwololo, M. (2008) Cast out for one mistake: a cry for help. The Daily Nation. The Family Magazine p.6-7. Nation Media Group Ltd.

Muganda, B. N. (1997). Effects of Dropping out of Secondary Education among Girls in Kenya: A Case Study of Shinyalu Division, Kakamega District.

Moi University: Unpublished MPhil.Thesis.

Ochieng, M. A. (2005). A study of the reproductive and sexual-health behavior of adolescents in Kisumu district, in relation to HIV/AIDS. Unpublished thesis. Maseno University.

Odebero, O. S. (2009). Bursary as a Method of Financing Secondary School Education in Busia District. Unpublished Masters thesis. Maseno University.

Oghuvbu, E. P. (2010). Attendance and Academic Performance of Students in Secondary schools; A Correlational Approach. Unpublished Thesis. Delta State University.

Oghuvbu, E. P. (1998). Classroom Management Problems in Urban primary Schools in Delta State University. West Africa Journal of Educational Research. Vol 11 P 159-164

Ogutu, J. (2008). Why plan to allow pregnant girls back to school faild.The Standard Newspaper Ltd. p5.

Okumbe, J. O. (2001). Human Resource Management: An Educational perspective. Nairobi: Education and Research Bureau, Kenyatta University.

Ombuya, B. D., Yambo, J. M. O., \& Omolo, T. M. (2012) Effects of Orphan hood on Girl-child's Access and Retention in Secondary School Education: A case of Rongo Dist, Kenya. International journal of Academic Research in Progressive education and Development $4(1): 114-136$

Omondi, G. (2008). Report sounds alarm over teenage pregnancy. The Daily Nation.p15.

Olembo, J., \& Namswa, E. (1982), Financing Primary School Education in KenyaDiscussion Paper No 1092. Nairobi : Bureau of Educational Research, Kenyatta Uni

Oloo, M. A. (2003). Gender Disparity in Students' Performance in KCSE in Mixed day Secondary Schools in Migori District. Unpublished Masters thesis. Maseno Uni.

Olweya, J. A. (1996). Educational Wastage among Girls in Kenyan Secondary Schools A Case study of Homa Bay District. Moi University: Unpublished MPhil. Thesis.

Onouwuodeke, M. A. (1995). The Management of Students' Learning problems. Delta Journal of Educational Development.Abraka. Vol3 P81-90

Orodho, A. J. (2003). Essentials of Education and Social Science Research Methods. Nairobi: Mazola Publishers.

Osodo, J. M. (2008) Impact of Socio- Economic Factors that Hinder Promotion of Secondary school Education in Kenya. Unpublished master's thesis Maseno Uni.

Ouma, R. (2002) "The Status of Youth and Children in Kenya- A Review of the

Implementation of Agenda 21 in Kenya" - Unpublished paper presented at the Kenya NGO Earth Summit 2002 Forum

Papalia, D. E., \& Olds, S. W. (1990). A child's world: infancy through adolescence. New York: Mc Graw Hill.

Psacharoupoulos, G., \& Woodhall, M. (1995). Education for Development: An analysis of Investment choices. Washington D.C.Oxford University University.

Republic of Kenya. (1976). Gachathi Report. Nairobi: Government Printer 
Republic of Kenya. (2009). Homa Bay District Development Plan 2008-2011.

Nairobi: Government Printer.

Republic of Kenya. (2009). Rongo District Development Plan 2008-2011.

Nairobi: Government Printer.

Republic of Kenya. (2009) Kenya National Bureau of Statistics. Nairobi. saz Government Printer.

Republic of Kenya. (1998). Master Plan on Education and Training 1997-2010. Nairobi: Jomo Kenyatta Foundation.

(1999). National Poverty Eradication Plan 1999- 2015. Nairobi: Govt Printer.

(2002). Economic Survey 2002. Nairobi: Government Printer.

Runberger, W. R. (2001). Who Drops out of School and Why? Paper prepared for National Research Council, Committee on Educational Excellence and Testing Equity Workshop.Washington DC.

Sathe, A. G. J. (1994). Introduction of Sex Education on Schools: Perception of Indian Society. The journal of Family Welfare, P8.

Simatwa, E. W. S. (2007). Management of Student Discipline in Secondary Schools in Bungoma District. Unpublished PHD Thesis. Maseno University.

Siringi, S. (2002) "Mobile School sought for Nomads". Daily Nation P 20.

Slater, J. (2000). Britain sex education under fire. The Times Educational supplement. http://:www.unesco.org/courier/2000.07/uk/apprend:htm. Retrieved on 9/12/2011.

Somalia Media Centre. (2010). The Importance of Female Teachers and Education and Education for Girls. Mogadishu. Somalia Media Centre.

Spetz. (1995). The cost of Education for Low Income households. The case of Samburu Location, Kwale District. Unpublished report. University of Gothenburg.

Summer, L. (1994). Investigating in All the People: Educating Women in Developing countries. Washington D.C: World Bank.

UNDP. (1999). Human Development Report, 1999. Oxford:

Oxford University Press.

UNESCO. (1990). The Education for All; Teacher Training Package, Vol. 2, UNESCO: Nrb

UNESCO. (1995). The Education of Girls and Women: Towards a Global Framework for Action. France: UNESCO.

UNESCO Institute for Statistics. (2005). Global Education Digest 2005. Montreal: UNESCO Institute for Statistics, Montreal.

UNICEF. (1992). The girl child: Opportunities and disparities in education. Workshop Report. Nairobi: UNICEF

UNICEF \& OAU. (1992). Situation Analysis of Women and Children in Kenya. Nrb Gvt Printers UNICEF (1998). The State of the Worlds' Children 1998. New-York: UNICEF.

Vilija, G. (1997). Students' Attitude towards Education and the Future since the Restoration of Lithuania's Independence (1990-1995). Lithuanian Quarterly Journal of Arts and Science. Vol.43. No. 4. P12.

Wanyama, E. G. A. (2011). Challenges and Prospects in Implementation of Re-entry Policy of Girls in Secondary Schools in Emuhaya District. Unpublished Masters Thesis. Maseno University.

Wamahiu, S., \& Njau, W. (1995). School Girl Drop Out and Adolescent Pregnancy: Counting the Cost. Basic Education Forum Vol. 6, No 6. P10.

Watkins, J. (2000) The Oxfam Education Report. Oxford: Oxfam.

Weeks, S. G. 1963). Report on Sociological Case Study of Urban Day 
Secondary School. In Castle F.B. Growing up in East Africa. London: OUP Werk, J. (2004) Participation of Orphaned and Vulnerable Children in Free Primary Education in Kenya, Werk. Report.

Woodhall, M. (2004). Analysis in Educational Planning Cost Benefit. Paris: UNESCO.

World Bank. (1995). Education in Sub- Saharan Africa, Policies for Adjustments. Washington D.C: World Bank.

World Bank. (1998). A chance for every child. Washington D.C: World Bank.

World Bank. (2002). A chance for learning, knowledge and financing for Education in SubSaharan Africa. Washington D.C: World Bank.

World Ban. (2004). Expanding Opportunities and Building Competencies for Young People: A new Agenda for Secondary Education . World Bank;Washington , DC.:

Yambo, J. M. O. (2012). Determinants of KCSE Examination Performance in SDA Sponsored Schools: A Key to Academic Promotion to the next Level of Learning. Lambert Academic Publishing. Saarbrucken, Germany 